\title{
Bagaimana Menjadi Orang Tua Anak dengan Cerebral Palsy?
}

\section{A Parent Acceptance}

\author{
(How to be Parent of Children with Cerebral Palsy? A Parent Acceptance)
}

Yubaedi Siron', Veda Ria Perdana², Sri Rahayu Saputri³, Dewi Nur Hanifah ${ }^{4}$

${ }^{1234}$ Pendidikan Islam Anak Usia Dini, Universitas Islam Negeri Syarif Hidayatulllah Jakarta 1yubaedi.siron@uinjkt.ac.id, ${ }^{2}$ vedariap@gmail.com, ${ }^{3}$ srirahayusaputri40@gmail.com,

${ }^{4}$ dewinurhan@gmail.com

*)corresponding author

$\begin{array}{lcc}\text { First received: } & \text { Revised: } & \text { Final Accepted: } \\ 02 \text { August } 2020 & 06 \text { October } 2020 & 29 \text { December 2020 }\end{array}$

\begin{abstract}
Parents who have down syndrome children find it challenging to accept the presence in their early stages of life, even though parental acceptance becomes the primary factor of the successful parenting of children with cerebral palsy. This study aims to describe the acceptance of parents who have children with cerebral palsy. This study uses a qualitative approach using the phenomenological method for revealing the phenomenon of parents' compliance with cerebral palsy children. The data collection technique uses structured interviews involving 5 participants. The results of this study indicated that parents are trying to accept the child's condition by being grateful, surrendering, socializing, and sharing information with fellow parents of children with cerebral palsy. Support from the closest relatives and friends is an essential factor that makes the process of acceptance easier for parents to undertake.
\end{abstract}

Keywords: cerebral palsy, acceptance, parent, parenting

\begin{abstract}
Abstrak
Orang tua yang mempunyai anak down syndrome sulit menerima kehadiran di fase awal kehidupannya, padahal penerimaan orangtua menjadi faktor utama dalam suksesnya pengasuhan anak dengan cerebral palsy. Penelitian ini bertujuan untuk mendeskripsikan penerimaan orang tua yang memiliki anak dengan cerebral palsy. Penelitian ini menggunakan pendekatan kualitatif dengan menggunakan metode fenomenologi untuk mengungkap fenomena penerimaan orang tua anak cerebral palsy. Teknik pengumpulan data menggunakan wawancara terstruktur dengan melibatkan 5 partisipan. Hasil penelitian ini menunjukkan bahwa yang dilakukan para orangtua untuk dapat menerima kondisi anak yaitu dengan cara bersyukur, berserah diri, bergaul dan berbagi informasi dengan sesama orangtua dari anak dengan cerebral palsy. Dukungan dari orang-orang terdekat juga menjadi salah satu faktor penting yang membuat proses penerimaan menjadi lebih mudah dijalani oleh orangtua.
\end{abstract}

Kata kunci: cerebral palsy; penerimaan; orang tua, pengasuhan

\section{PENDAHULUAN}

Setiap orang tua berharap anaknya terlahir dengan kondisi sehat dan berkembang sesuai dengan tahapan perkembangannya. Namun, tidak semua keinginan dapat terwujud sesuai dengan yang diinginkan, karena setiap anak terlahir dengan berbagai macam kondisi (Wulandari \& Suryanto, 2020). Anak cerebral palsy membutuhkan sesuatu yang dapat membantunya beraktivitas layaknya anak normal pada umumnya. Seiring bertambahnya usia, anak seharusnya telah melewati fase-fase perkembangan, dan 
salah satunya adalah perkembangan dalam aspek psikomotorik (Davies, 2011).

Cacat fisik atau mental saat lahir atau selama pertumbuhan dan perkembangan memaksa keluarga untuk melewati tahapan shock, penolakan, rasa bersalah, kecemasan dan menyebabkan stres bagi seluruh keluarga (Macintyre, 2007; McFarland-Piazza \& Saunders, 2012; Plows \& Whitburn, 2017), termasuk bagi orang tua yang memiliki anak cerebral palsy. Cerebral palsy adalah perubahan fungsi motorik yang ditimbulkan akibat kerusakan pada susunan saraf pada rongga tengkorak. Namun cerebral palsy tidak hanya menyebabkan kelainan motorik, tetapi juga menimbulkan beberapa gangguan yaitu seperti epilepsi, kesulitan komunikasi, gangguan belajar, serta gangguan persepsi dan perilaku (Rosenbaum P, Paneth N, Leviton A, 2007).

Ibu yang mengasuh anak cerebral palsy mengalami stres yang lebih dari pada ibu pada umumnya (Ikasari \& Kristiana, 2017). Akan tetapi, penerimaan orangtua terhadap kondisi anak menjadi faktor yang utama dalam pengasuhan anak Cerebral palsy (Pradipta \& Andajani, 2017). Penerimaan diartikan sebagai tindakan pengasuhan yang dilakukan oleh orangtua yang ditandai dengan adanya kehangatan, kasih sayang, perawatan, kenyamanan, perhatian, pemeliharaan, dukungan dan cinta kepada anak (Dwairy, 2009; Fernández-García, Rodríguez-Menéndez, \& Peña-Calvo, 2017; Whittingham, Sanders, McKinlay, \& Boyd, 2013). Penerimaan Ibu terhadap seorang anak terlihat dari perilakunya yang mencerminkan perhatian dan cinta kasih ketika dalam pengasuhan (Wahyuni, 2017).

Beberapa karakteristik keluarga yang dapat dikatakan sukses dalam mengasuh anak berkebutuhan khusus yaitu penerimaan kondisi anak, menerima peran pengasuhan yang tidak biasa dari kondisi anak, kemampuan koping kognitif yang mempengaruhi kemampuan adaptasi terhadap perubahan kebutuhan anak (Fernández-García et al., 2017; Lindsay, Proulx, Scott, \& Thomson, 2014). Pencapaian aspek-aspek dari penerimaan diri itu sendiri yaitu mampu mempunyai sikap yang sadar akan realitas, adanya pemahaman tentang diri sendiri, mampu menjaga keseimbangan antara real self dan ideal self melalui evaluasi diri, serta menerima kelemahan dan kekuatan diri sendiri yang mendasar (Amodei, Jalongo, Myers, Onchwari, \& Gargiulo, 2013; Harris \& Steyn, 2014; Samuel Kirk, James J Gallagher, Mary Ruth Coleman, 2009).

Ketika dokter mendiagnosa kondisi anak dengan Cerebral palsy, orangtua mengalami beberapa emosi, seperti marah, rasa tidak percaya, bahkan sedih (Prasastiwi \& Hardjanta, 2017; Sakdiyah, 2012; Wahyuni, 2017). Penolakan orangtua terhadap pengasuhan anak berkebutuhan khusus ditandai dengan tidak adanya kasih sayang, perawatan, kenyamanan, kepedulian, dan dukungan atau cinta yang diberikan pada anak (Eliyanto \& Hendriani, 2013; Prasastiwi \& Hardjanta, 2017; Rosenbaum P, Paneth N, Leviton A, 2007). Penolakan pengasuhan yang dilakukan oleh orang tua mengakibatkan munculnya sifat agresif pada anak dan pandangan yang negatif anak terhadap dunia, anak memandang orang lain sebagai suatu ancaman bagi dirinya. Padahal, orang tua memiliki peran yang penting dalam berpartisipasi untuk penanganan anak (Siron, 2019).

Partisipasi dari orang tua dalam penanganan anak cerebral palsy memiliki nilai yang lebih menguntungkan bagi anak. Pola asuh merupakan faktor yang dapat 
memprediksikan kualitas hidup anak dengan cerebral palsy (Aran, Salev, 2007) sehingga perlu adanya peningkatan kapasitas orangtua dalam keluarga tentang pengetahuan dan penanganan pada anak dengan kondisi cerebral palsy yaitu pendampingan dari tenaga ahli kepada orangtua (Anindita \& Apsari, 2020; Harjani, 2020; Pradipta \& Andajani, 2017; Whittingham et al., 2013).

Beberapa penelitian terkait sudah dilakukan, misalnya tentang pengalaman Ibu dalam merawat anak Cerebral palsy (Kusumah, 2017), hubungan kecerdasan emosi dengan penerimaan ibu terhadap anak kandung yang mengalami cerebral palsy (Eliyanto \& Hendriani, 2013), hubungan antara regulasi emosi dengan stress pengasuhan ibu yang memiliki anak cerebral palsy (Ikasari \& Kristiana, 2017), serta hubungan antara pengalaman orangtua dalam perawatan kualitas hidup anak cerebral palsy di Yogyakarta (Puspitarini, 2017).

Penelitian ini bertujuan untuk mengetahui sejauh mana orang tua dapat menerima kehadiran anak dengan cerebral palsy, dimana sikap penerimaan yang sepenuhnya dilakukan oleh orang tua dari anak cerebral palsy yaitu berupa adanya kasih sayang, kenyamanan, perhatian, dan perawatan dari orang tua tersebut. Selain itu dengan adanya penerimaan ini bisa lebih menyadarkan beberapa pemahaman orang tua cerebral palsy tentang diri sendiri, pola asuh yang baik bagi anak, dan konsep diri dari orang tua cerebral palsy dalam kesadaran atau evaluasi diri sendiri.

\section{METODE}

Penelitian ini menggunakan pendekatan kualitatif dengan metode studi kasus. Teknik pengumpulan data dalam penelitian ini melalui wawancara terstruktur secara daring. Penelitian ini melibatkan 5 partisipan yang dipilih menggunakan purpossive sampling. Kriteria partisipan yaitu orang tua yang memiliki anak dengan cerebral palsy dan pernah mengalami pergolakan penerimaan kehadiran anaknya hingga akhirnya mereka menerima kehadirannya dan menstimulasi dengan baik. Peneliti membuka open comment di media sosial untuk menjaring orang tua yang mempunyai anak cerebral palsy yang bersedia untuk diwawancarai. Selain itu, peneliti membuat broadcast kepada publik untuk memberikan tanggapan kepada peneliti untuk penjaringan partisipan. Setelah calon data partisipan masuk, terpilih 5 partisipan yang sesuai dengan kriteria penelitian.

Tabel.1 Data Partisipan

\begin{tabular}{cll}
\hline No & & Data Partisipan \\
\hline 1 & Usia anak CP & 6 tahun 6 bulan \\
& Usia orang tua & 33 tahun dan 36 tahun \\
& Pekerjaan & Ibu rumah tangga \& Karyawan swasta \\
& Alamat & Bandar Lampung \\
\hline 2 & Usia anak CP & 5 tahun \\
& Usia orang tua & 31 tahun \& 32 tahun \\
& Pekerjaan & Ibu rumah tangga \& Karyawan swasta \\
& Alamat & Jakarta Selatan \\
\hline 3 & Usia anak CP & 5 tahun \\
& Usia orang tua & 32 tahun \& 35 tahun \\
& Pekerjaan & Ibu rumah tangga \& Pegawai swasta \\
& Alamat & Jakarta Selatan \\
\hline
\end{tabular}




\begin{tabular}{cll}
\hline No & & Data Partisipan \\
\hline 4 & Usia anak CP & 5 tahun \\
& Usia orang tua & 30 tahun \& 30 tahun \\
& Pekerjaan & Ibu rumah tangga \& Karyawan swasta \\
& Alamat & Depok \\
\hline 5 & Usia anak CP & 12 Tahun \\
& Usia orang tua & 53 Tahun \& 53 Tahun \\
& Pekerjaan & Wiraswasta \\
& Alamat & Surabaya \\
\hline
\end{tabular}

Teknik analisis data dalam penelitian ini menggunakan Miles dan Huberman dengan mereduksi data, menyajikan data, dan melakukan verifikasi/simpulan.

\section{HASIL TEMUAN DAN PEMBAHASAN}

\section{Perasaan ketika mengetahui anak didiagnosa menderita cerebral palsy}

Pada kategori pertama yaitu membahas tentang perasaan yang dirasakan oleh orang tua pertama kali ketika mengetahui anaknya terdiagnosa menderita cerebral palsy. Pada kategori ini terdiri dari 4 kode. Responden menyatakan bahwa terdapat perasaan hancur, sedih, kaget, syok, hingga menangis ketika mengetahui anaknya didiagnosa menderita cerebral palsy, yang dimana hal ini membuat sebagian besar orang tua menutup diri dari publik, media sosial dan masyarakat sekitar. Orangtua pun memerlukan waktu untuk dapat berdamai dengan diri sendiri, tidak menyalahkan keadaan sehingga bisa sepenuhnya menerima kondisi dan keadaan anak. Studi mengungkapkan stress yang dialami orang tua merupakan hal yang wajar (Biswas, Moghaddam, \& Tickle, 2015; Jones, 1991; Leitch et al., 2019; Perez Algorta et al., 2018). Studi yang dilakukan di Jerman (Sarimski, Hintermair, \& Lang, 2013), Inggris (Akbar \& Woods, 2020), dan Indonesia (Meiza, Kardinah, Rahman, \& Puspasari, 2019) juga menunjukkan variasi stress orang tua yang bermacam-macam yang mendapati anaknya mempunyai kategori berkebutuhan khusus.

Tabel 2. Perasaan Ketika Mengetahui Anak Didiagnosa CP

\begin{tabular}{|c|c|c|c|}
\hline \multicolumn{2}{|l|}{ Kategori } & Kode & \multirow{2}{*}{$\begin{array}{l}\text { Kutipan } \\
\text { Pertama didiagnostik usia } 8 \text { bulan, perasaannya } \\
\text { sedih, hancur, merasa bersalah tidak } \\
\text { diperiksakan dari awal.(n5) }\end{array}$} \\
\hline \multirow{3}{*}{$\begin{array}{l}\text { Perasaan } \\
\text { mengetahui } \\
\text { didiagnosa } \\
\text { menderita } \\
\text { (Cerebral palsy) }\end{array}$} & $\begin{array}{r}\text { Ketika } \\
\text { anak }\end{array}$ & $\begin{array}{l}\text { Perasaannya Hancur (n1) (n2) } \\
\text { (n5) }\end{array}$ & \\
\hline & $\mathrm{CP}$ & $\begin{array}{l}\text { Merasa sedih karena butuh } \\
\text { waktu untuk berdamai dengan } \\
\text { diri sendiri (n1) (n5) }\end{array}$ & $\begin{array}{l}\text { Perasaan kami pertama kali anak kami } \\
\text { didiagnosa CP pastinya hancur, terus ga bisa } \\
\text { terima terus sedih, jadi bawaannya nangiS terus } \\
\text { dan berusaha nyari penyebabnya apa? Harus } \\
\text { menyalahkan siapa? intinya apa ya? Sedih } \\
\text { berkepanjangan lah..karna butuh waktu buat }\end{array}$ \\
\hline & & $\begin{array}{l}\text { Nangis setiap hari karena } \\
\text { harapan dan cita-cita seketika } \\
\text { musnah (n1) (n2) }\end{array}$ & $\begin{array}{l}\text { Saat tau B cp pada usia } 8 \text { bulan jujur saja hati } \\
\text { saya hancur banget, stress, nangis setiap hari, } \\
\text { semua harapan dan cita-cita yang dibayangkan } \\
\text { saat hamil seketika musnah. Sempat Baby Blues } \\
\text { juga beberapa lama, tapi Alhamdulillah suami } \\
\text { sabar selama melalui itu semua (n2) }\end{array}$ \\
\hline
\end{tabular}




\begin{tabular}{lll}
\hline \multicolumn{1}{c}{ Kode } & \multicolumn{1}{c}{ Kutipan } \\
\hline Kaget dan bertanya & mengapa & Pertama mungkin karena belum paham jadi \\
bisa begini (n4) & kaget, bertanya kenapa bisa begini. Tapi setelah \\
& dijalani mau 5 tahun, yaaa sudah terima saja \\
& yang sudah ditakdirkan Allah (n4)damai \\
& dengan diri sendiri. (n1) \\
\hline
\end{tabular}

\section{Emosi yang Dirasakan Ketika Mengetahui anak menderita $\mathbf{C P}$}

Pada kategori kedua yaitu membahas tentang keadaan depresi, emosi yang tidak stabil, rasa bersalah serta frustasi yang dirasakan oleh Orangtua saat mengetahui bahwa anaknya menderita cerebral palsy. Pada kategori ini terdiri dari 3 kode. Responden menyatakan bahwa saat mereka mengetahui anaknya menderita cerebral palsy, sebagian besar orang tua mengalami depresi, frustasi hingga stress yang disebabkan karena adanya perasaan kecewa, harapan yang diinginkan saat masa hamil musnah, menyalahkan keadaan, serta pandangan dan omongan orang sekitar terhadap anak tersebut. Fluktuasi emosi yang dialami orang tua cukup variatif (Putnick et al., 2012), stress, tertekan, pasrah menjadi hal pertama yang biasa orang tua alami (Biswas et al., 2015; Leitch et al., 2019; Perez Algorta et al., 2018).

Tabel 3. Emosi yang dirasakan Ketika Mengetahui Anak Menderita CP

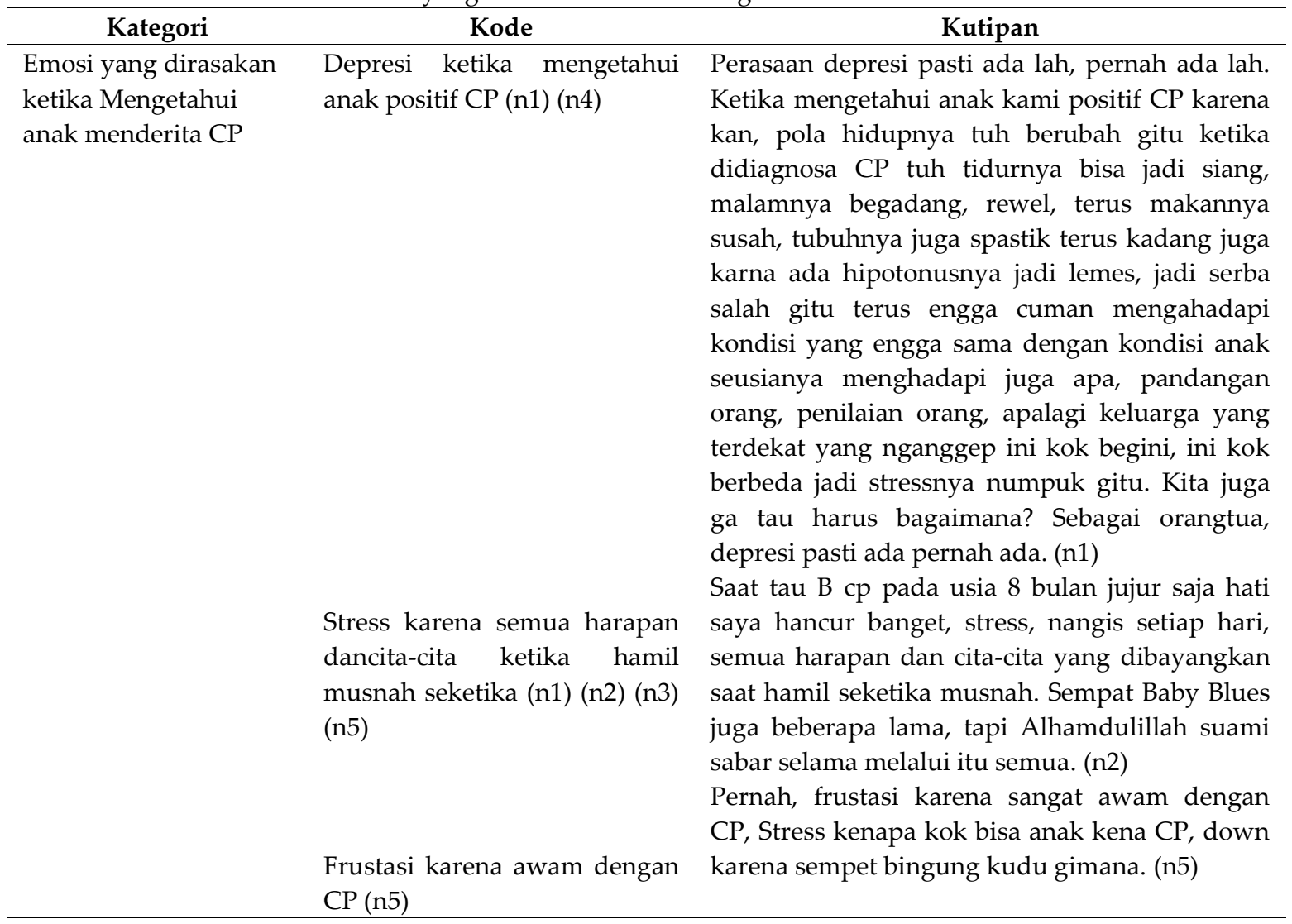

Respon didapatkan dari keluarga, saudara, teman dan masyarakat
Pada kategori ketiga yaitu membahas tentang respon dari keluarga, 
saudara, teman dan masyarakat sekitar terhadap anak cerebral palsy. Pada kategori ini terdiri dari 2 kode. Responden mengatakan bahwa respon yang diberikan dari saudara, teman dan masyarakat berbeda-beda, ada yang memberikan respon positif dan respon yang negatif. Bentuk respons positif seperti: mampu menerima dengan ikhlas, memberi dukungan serta memberi nasihat-nasihat yang baik. Bentuk respon negatif seperti: menyalahkan sang ibu yang kurang merawat saat hamil, berkata sebagai kutukan dan berpikir bahwa hal ini dapat terjadi dikarenakan dosa masa lalu. Respon yang didapatkan dari anggota keluarga terhadap kondisi anaknya bermacam variasinya (Rohner, 2014) (Machado, Machado, Neves, \& Fávero, 2014). Tapi, penerimaan anggota keluarga terhadap anaknya akan berdampak positif pada psychological adjustment anak (Filus \& Roszak, 2014; Glavak-Tkalić \& Kukolja-Cicmanović, 2014; Machado et al., 2014; Rohner, 2014; Varan, Rohner, \& Eryuksel, 2008). Begitu juga kesepakatan antar anggota keluarga merupakan faktor yang penting (Putnick et al., 2012).

Tabel 4. Respon dari keluarga, saudara, teman dan masyarakat.

\begin{tabular}{|c|c|c|}
\hline Kategori & Kode & Kutipan \\
\hline $\begin{array}{l}\text { Respon didapatkan dari } \\
\text { keluarga, saudara, teman } \\
\text { maupun masyarakat } \\
\text { sekitar } r \text { ketika } \\
\text { mengetahui bahwa } \\
\text { ibu/bapak memiliki anak } \\
\text { yang menderita } \\
\text { palsy }\end{array}$ & $\begin{array}{l}\text { Menyalahkan ibunya, sebagai } \\
\text { kutukan, dosa masa lalu (n1) } \\
\text { (n5) }\end{array}$ & $\begin{array}{l}\text { Alhamdulillah semua baik. keluarga saya } \\
\text { ikhlas jika memang harus jaga anak special. } \\
\text { orang tua dan mertua juga mendukung, } \\
\text { mereka memberi nasihat kalo ini bisa } \\
\text { dijadikan lading pahala. (n3) } \\
\text { Respon orang terdekat pertama-tama ketika } \\
\text { tau anak kami CP itu pastinya menyalahkan } \\
\text { ibunya, dianggap kurang. Waktu hamil } \\
\text { kurang sayur, kurang makan, padahal kan } \\
\text { setiap bulan USG, setiap bulan mendapat } \\
\text { vitamin dapat apa, suplemen dari dokter } \\
\text { kandungan, setiap bulan USG, ga pernah } \\
\text { nggak USG gitu kan. Terus menganggap ini } \\
\text { kutuk. apa istilahnya dosa dari kesalahan } \\
\text { orang tua dan segala macem lah pokoknya } \\
\text { aib dianggap aib intinya kaya gitu. Akibat } \\
\text { dosa masa lalu gitu lah intinya (n1) }\end{array}$ \\
\hline
\end{tabular}

Bentuk support yang diterima dari keluarga, teman dan lingkungan sekitar

Pada kategori keempat yaitu membahas mengenai bentuk support yang didapat oleh orangtua dari anak Cerebral palsy dari keluarga, teman dan masyarakat sekitar. Pada kategori ini terdiri dari 3 kode. Responden mengatakan bahwa dari pihak keluarga, teman dan masyarakat sekitar memberikan support yang beragam, seperti memberi dukungan, mengerti dan memahami kondisi anak, memberi semangat, memberi bantuan berupa material dan memberi nasihat yang bersifat membangun. Dukungan dan keterlibatan keluarga menjadi salah satu faktor pendorong keberhasilan pengasuhan anak berkebutuhan khusus (Grace, Bowes, \& Elcombe, 2014; Grisham-Brown \& Mccormick, 2013; Richard M. Gargiulo, 2005). Belief system yang dimiliki keluarga mempunyai peranan yang penting dalam hal ini (King, Baxter, Rosenbaum, Zwaigenbaum, \& Bates, 2009). 
Bagaimana Menjadi Orang... - Yubaedi Siron, Veda Ria Perdana, Sri Rahayu Saputri \& Dewi Nur Hanifah

Tabel 5. Bentuk Support yang Diterima Dari Keluarga dan Lingkungan Sekitar

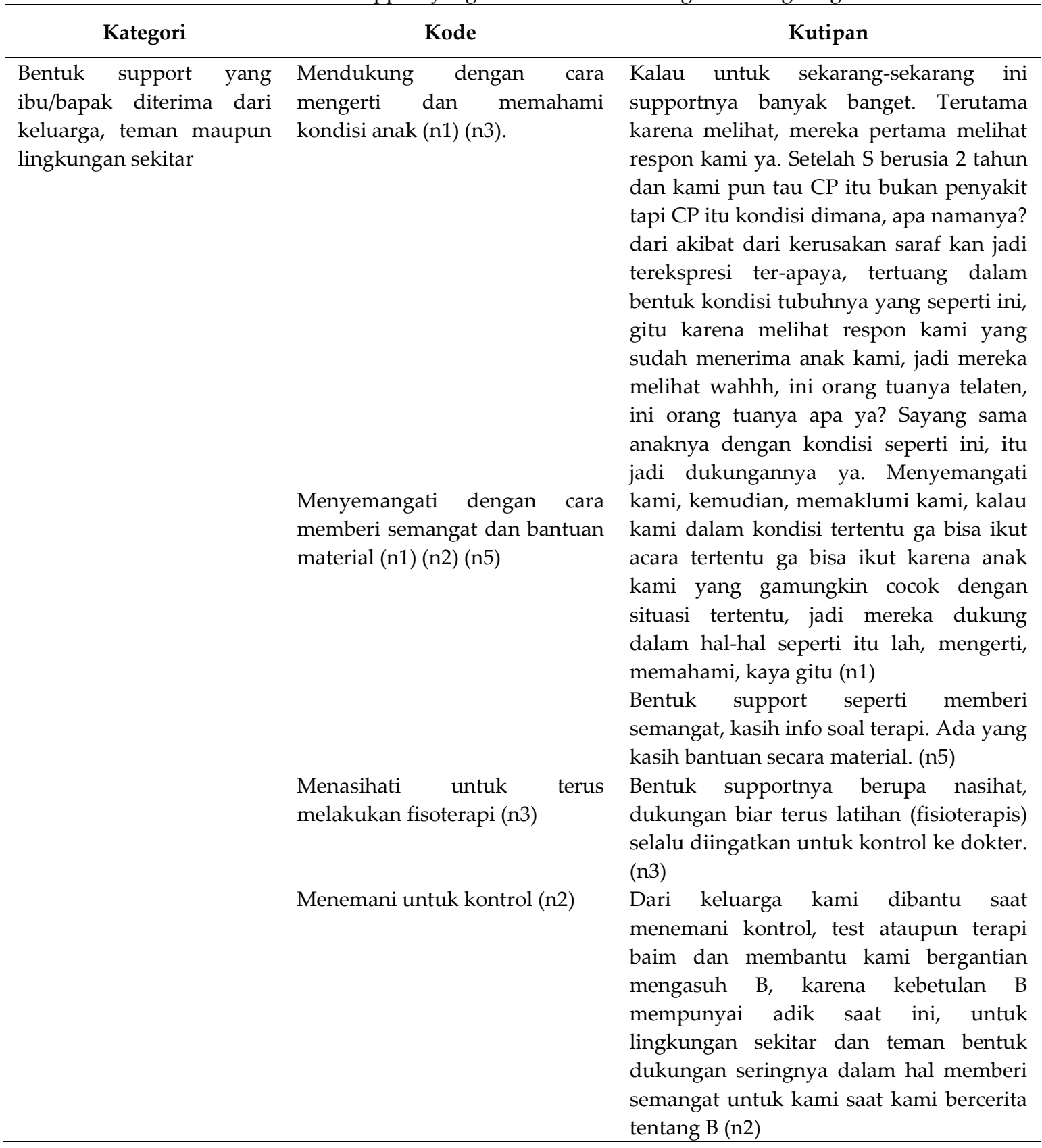

\section{Terintas dipikiran memiliki anak cerebral palsy menjadi sebuah "Aib" bagi keluarga}

Pada kategori kelima yaitu membahas mengenai cara pikir Orang tua yang menganggap bahwa memiliki anak penderita Cerebral palsy merupakan sebuah 'aib' bagi keluarga. Pada kategori ini terdiri dari 2 kode. Responden mengatakan bahwa sempat memiliki pikiran bahwasannya anak dengan Cerebral palsy merupakan sebuah aib bagi keluarga, namun ada pula yang berpikiran sebaliknya. Dan mereka sebagai orangtua mampu menepis atau membuang pikiran buruk terhadap anaknya sehingga yang ada hanya rasa syukur, perasaan cinta dan kasih sayang untuk anak tersebut. 
Bagaimana Menjadi Orang... -Yubaedi Siron, Veda Ria Perdana, Sri Rahayu Saputri, Dewi Nur Hanifah

Tabel 6. Berfikir Bahwa Memiliki Anak CP Menjadi ‘Aib’ Bagi Keluarga

\begin{tabular}{|c|c|c|}
\hline Kategori & Kode & Kutipan \\
\hline $\begin{array}{l}\text { Berfikir bahwa memiliki } \\
\text { anak yang menderita } \\
\text { cerebral palsy ini menjadi } \\
\text { sebuah "Aib" bagi keluarga }\end{array}$ & $\begin{array}{l}\text { Sempat berfikir bahwa } \mathrm{CP} \\
\text { merupakan sebuah "aib" } \\
\text { (n2) }\end{array}$ & $\begin{array}{l}\text { Awalnya iya kami menganggap ini aib } \\
\text { bagi keluarga kami, sebab kami menarik } \\
\text { diri dari keluarga karena, jangan sampai } \\
\text { keluarga kami ini malu dengan kondisi } \\
\text { anak kami, tapi itu tahun-tahun pertama } \\
\text { kedua ketika kami belum tahu kalau itu } \\
\mathrm{CP} \text {, karena kami kira kan itu penyakit } \\
\text { ya, rupanya ini kondisi gitu jadi setelah } \\
\text { sekarang ya kami berusaha.. } \\
\text { menjelaskan secara pelan-pelan CP ini } \\
\text { gini loh, CP ini bukan penyakit, CP ini } \\
\text { bukan menular, CP ini juga } \\
\text { penyebabnya macem-macem pokoknya } \\
\text { sedikit-sedikit mengedukasi jadi mereka } \\
\text { juga sekarang sudah tau, oh ini gini..oh } \\
\text { ini gini.. gitu, jadi intinya kaya gitu sih } \\
\text { mba. (n1). }\end{array}$ \\
\hline
\end{tabular}

Faktor-faktor yang membuat orang tua dapat menerima keadaan anak tersebut

Pada kategori ketujuh yaitu membahas tentang faktor yang membuat orangtua dapat yang menerima anak dengan Cerebral palsy. Faktor tersebut dapat berupa dukungan dari keluarga, latar belakang agama, tingkat pendidikan kedua orang tua, dan juga status pernikahan.Pada kategori ini terdiri dari 3 kode. Responden mengatakan tentang pemahaman orang tua dalam Cerebral palsy, bagaimana cara menanganinya, lalu dalam faktor agama tentunya memiliki pemahaman kalau merawat anak sebagai dari ladang pahala bagi orang tuanya dan faktor utamanya yaitu penerimaan kondisi pada anak. Parental acceptance setiap orang tua berbeda-beda tipe, cara dan waktunya (Dwairy, 2009; FernándezGarcía et al., 2017; Machado et al., 2014; Putnick et al., 2012).

Tabel 8. Faktor-faktor yang Membuat Orang Tua Menerima Keadaan Anak

\begin{tabular}{|c|c|c|}
\hline Kategori & Kode & Kutipan \\
\hline \multirow{5}{*}{$\begin{array}{l}\text { Faktor-faktor yang membuat } \\
\text { ibu/bapak dapat menerima } \\
\text { keadaan anak tersebut (ex: } \\
\text { dukungan dari keluarga besar, } \\
\text { faktor ekonomi keluarga, latar } \\
\text { belakang agama, tingkat } \\
\text { pendidikan pasangan suami } \\
\text { istri, status perkawinan, usia } \\
\text { orangtua, sarana penunjang }\end{array}$} & $\begin{array}{l}\text { Faktor edukasi mengenai CP } \\
(\mathrm{n} 1)(\mathrm{n} 4)(\mathrm{n} 5)\end{array}$ & $\begin{array}{l}\text { Pertama tentu saat pemahaman } \\
\text { tentang } \mathrm{CP} \text { itu sendiri, yang } \\
\text { melingkup apa itu pemicunya dan } \\
\text { bagaimana penanganannya. (n4) }\end{array}$ \\
\hline & Agama yang mengajarkan & Kedua faktor agama tentu saja dengan \\
\hline & $\begin{array}{l}\text { bahwa anak merupakan ladang } \\
\text { pahala (n2) (n3) (n4) (n5) }\end{array}$ & $\begin{array}{l}\text { pemahaman keilmuan, karena kalau } \\
\text { hanya sebagai ladang pahala dan }\end{array}$ \\
\hline & & $\begin{array}{l}\text { sebagainya. Tentunya harus ditanami } \\
\text { dengan perlakuan dan penanganan, } \\
\text { perawatan anak yang akan ditimbang } \\
\text { sebagai hasil dari ladang pahala itu } \\
\text { sendiri. Setiap anak adalah ladang } \\
\text { pahala bagi orang tua, jadi bukan } \\
\text { hanya ABK yang jadi ladang pahala. } \\
\text { (n4) }\end{array}$ \\
\hline & Ekonomi merupakan salah satu & Faktor ekonomi, kami \\
\hline
\end{tabular}


Bagaimana Menjadi Orang... -Yubaedi Siron, Veda Ria Perdana, Sri Rahayu Saputri, Dewi Nur Hanifah

\begin{tabular}{|c|c|c|}
\hline Kategori & Kode & Kutipan \\
\hline & $\begin{array}{l}\text { faktor yang membuat orangtua } \\
\text { dapat menerima }(n 4)\end{array}$ & $\begin{array}{l}\text { mengalami fase dimana kami tak } \\
\text { mampu memberikan terapi yang } \\
\text { terbaik. Tapi dengan kemajuan } \\
\text { teknologi, kami menggunakan gadget } \\
\text { untuk mencari tahu terapi dan apa } \\
\text { saja yang bisa dilatihkan pada anak } \\
\text { kami. Jadi faktor utama nya } \\
\text { penerimaan kondisi anak adalah } \\
\text { pemahaman orangtua akan kondisi } \\
\text { anakitu sendiri. (n4) }\end{array}$ \\
\hline
\end{tabular}

\section{Motivasi untuk Bertahan}

Pada kategori kedelapan yaitu membahas mengenai motivasi yang bisa dijadikan alasan bagi Orangtua yang memiliki anak cerebral palsy untuk tetap bertahan terhadap kondisi yang dialami oleh anaknya.Pada kategori ini terdiri dari 3 kode. Responden mengatakan bahwasannya terdapat banyak hal yang dapat dijadikan motivasi bagi Orang tua, seperti ketika melihat perjuangan anak melawan sakit, harapan dan keinginan yang dimiliki Orangtua untuk bisa melihat anaknya mandiri meskipun dengan keterbatasan fisik, menerima kondisi anak, serta mencintai anaknya supaya anak selalu bahagia. Orang tua mempunyai dorongan yang berasal dari internal dirinya untuk dapat bertahan dalam mengasuh anaknya (McFarlandPiazza \& Saunders, 2012) yang didukung oleh belief system yang baik setiap orang tua dalam memposisikan dirinya dengan wujud kepasrahannya (Cohen, 2004; King et al., 2009).

Tabel 9. Motivasi untuk Bertahan

\begin{tabular}{|c|c|c|}
\hline Kategori & Kode & Kutipan \\
\hline \multirow[t]{2}{*}{$\begin{array}{l}\text { Motivasi untuk bertahan dalam } \\
\text { kondisi seperti ini }\end{array}$} & $\begin{array}{l}\text { Perjuangan anak melawan sakit } \\
\text { (n1) }\end{array}$ & $\begin{array}{l}\text { Yang jadi motivasi kami untuk bisa } \\
\text { bertahan sampai saat ini, sampai } \\
\text { masa-masa yang akan datang adalah, } \\
\text { mengingat perjuangan dia melawan } \\
\text { sakit, karna yaa } \mathrm{S} \text { kan gacuma CP tapi } \\
\text { kan dia punya riwayat kejang tanpa } \\
\text { demam, yang didiagnosa epilepsi, } \\
\text { jadi jangan ditanya berapa kali karna } \\
\text { udah nggak terhitung kejangnya itu, } \\
\text { berkali-kali masuk rumah sakit, } \\
\text { berkali-kali masuk ruang ICU, } \\
\text { tindakan apapun sudah dilakukan } \\
\text { dari usia dini bayi, jadi kalau } \\
\text { mengingat itu semua, rasanya bisa } \\
\text { dibilang hancur hati tapi melihat dari } \\
\text { kondisi saat ini sehat, walaupun } \\
\text { belum bisa mandiri. Ya itu lah yang } \\
\text { membuat kami kuat, yang bikin kami } \\
\text { bisa bertahan sampai saat ini, } \\
\text { perjuangannya untuk melawan sakit } \\
\text { itu luar biasa. (n1) }\end{array}$ \\
\hline & Melihat anak mandiri (n2) & $\begin{array}{l}\text { Motivasi kami ingin bisa melihat } B \\
\text { bisa mandiri suatu hari nanti dengan }\end{array}$ \\
\hline
\end{tabular}




\begin{tabular}{|c|c|c|}
\hline Kategori & Kode & Kutipan \\
\hline & & segala keterbatasan yg dia miliki (n2) \\
\hline & Mencari berkahnya (n3) & $\begin{array}{l}\text { Motivasinya biar dapat berkah aja } \\
\text { karena kasihan anak udah sakit, masa }\end{array}$ \\
\hline & Penerimaan kondisi anak (n4) & $\begin{array}{l}\text { dibiarin aja dan karena dia juga ngerti } \\
\text { kalo mau disayang. (n3) }\end{array}$ \\
\hline & $\begin{array}{l}\text { Melihat anak menjadi sehat } \\
\text { dan bahagia (n5) }\end{array}$ & $\begin{array}{lcc}\text { Penerimaan kondisi anak dan } & \text { an } \\
\text { mencintai } & \text { anak sebagaimana } \\
\text { seharusnya orang tua bersikap (n4) }\end{array}$ \\
\hline & & $\begin{array}{l}\text { Semoga Anak saya selalu bahagia, } \\
\text { sehat dan kelak usaha yg dia jalani } \\
\text { saat ini pasti akan ada hasilnya (n5) }\end{array}$ \\
\hline
\end{tabular}

\section{Cara untuk bisa sampai pada tahap menerima keadaan}

Pada kategori kesembilan yaitu mengenai bagaimana cara Orang tua dengan anak Cerebral palsy bisa sampai pada tahap menerima keadaan anaknya hingga sekarang. Pada kategori ini terdiri dari 3 kode. Responden mengatakan bahwa mereka memiliki cara tersendiri sehingga bisa sampai pada tahap penerimaan ini, seperti selalu bersyukur karena anaknya masih diberikan kesehatan untuk hidup, berserah kepada Tuhan yang maha kuasa dan juga dapat dipertemukan untuk berbagi kisah, pengalaman satu sama lain dengan Orang tua yang juga memiliki anak Cerebral palsy. Belief system (Cohen, 2004; King et al., 2009), penerimaan (Dwairy, 2009; Fernández-García et al., 2017; Machado et al., 2014; Putnick et al., 2012), dan motivasi internal (McFarland-Piazza \& Saunders, 2012) menjadi faktor penting orang tua untuk dapat menerima bagaimanapun kondisi anaknya.

Tabel 10. Cara untuk bisa sampai pada tahap menerima keadaan

\begin{tabular}{|c|c|c|}
\hline Kategori & Kode & Kutipan \\
\hline \multirow[t]{3}{*}{$\begin{array}{l}\text { Cara untuk bisa sampai pada tahap } \\
\text { menerima keadaan ini semua }\end{array}$} & $\begin{array}{l}\text { Bersyukur masih diberikan } \\
\text { kesehatan untuk hidup (n1) (n3) }\end{array}$ & $\begin{array}{l}\text { Yaa bersyukur lah intinya } \\
\text { bersyukur sekali masih diberikan } \\
\text { kesehatan untuk hidup, karena } \\
\text { beberapa kali, kayaknya kematian } \\
\text { itu deket banget, tapi masih aja } \\
\text { tuhan kasih kesempatan buat si } \\
\text { safat hidup, buat safat sehat sampai } \\
\text { saat ini, hanya itu si, bingung } \\
\text { ngomongnya apa yaa. gitu aja si } \\
\text { mba, bersyukur aja hahaha (n1) }\end{array}$ \\
\hline & $\begin{array}{l}\text { Berserah kepada Tuhan yang } \\
\text { maha kuasa (n2) (n3) }\end{array}$ & $\begin{array}{l}\text { Dengan berserah kepada Allah dan } \\
\text { meyakini bahwa semua ini sudah } \\
\text { suratan takdir dari Allah. Dengan } \\
\text { mencoba ibadah lebih khusyuk lagi. } \\
\text { Jadi hati merasa tenang gitu mba } \\
\text { menjalani ini semua. (n2) }\end{array}$ \\
\hline & $\begin{array}{l}\text { Bertemu, bergaul, berbagi kisah } \\
\text { dan saling belajar dengan } \\
\text { orangtua CP lain }(n 4)(n 5)\end{array}$ & $\begin{array}{l}\text { Bertemu dan bergaul serta berbagai } \\
\text { kisah dengan orangtua anak } \mathrm{CP} \\
\text { lainnya untuk saling belajar dan } \\
\text { menguatkan }(\mathrm{n} 4)\end{array}$ \\
\hline
\end{tabular}




\section{Suka \& duka yang dirasakan dalam mengurus anak Cerebral palsy}

Pada kategori kesepuluh yaitu mengenai suka dan duka yang dirasakan oleh Orang tua dalam mengasuh anak Cerebral palsy.Pada kategori ini terdiri dari 1 kode. Responden mengatakan bahwa perasaan suka yang mereka alami dan rasakan dapat berupa sikap lebih bisa menghargai hal-hal kecil yang dilakukan mulai dari perkembangan ataupun progress anak, dan perasaan duka yaitu ketika melihat anak-anak dari teman yang seusia nya bisa sekolah dan beraktivitas layaknya anak normal seusianya. Menjadi orang tua yang memiliki anak dengan kebutuhan khusus mempunyai sensasi yang bermacam-macam, stress bercampur kepuasan akan didapat orang tua saat pengasuhan ABK (Sarimski et al., 2013).

Tabel 11. Suka dan Duka dalam Mengurus Anak Cerebral palsy

\begin{tabular}{|c|c|c|}
\hline Kategori & Kode & Kutipan \\
\hline \multirow[t]{3}{*}{$\begin{array}{l}\text { Suka \& duka yang dirasakan dalam } \\
\text { mengurus anak Cerebral palsy }\end{array}$} & $\begin{array}{l}\text { Menghargai hal-hal kecil (n1) } \\
\text { (n2) (n3) (n4) (n5) }\end{array}$ & $\begin{array}{l}\text { Suka nya jadi lebih menghargai } \\
\text { hal-hal kecil dari perkembangan }\end{array}$ \\
\hline & $\begin{array}{l}\text { Mempunyai banyak teman } \\
\text { senasib (n1) (n2) (n3) (n4) (n5) }\end{array}$ & $\begin{array}{l}\text { banyak teman yang dari } \\
\text { komunitas yang senasib. Duka }\end{array}$ \\
\hline & $\begin{array}{l}\text { Anak tidak sesuai dengan } \\
\text { tahapan perkembangan }(\mathrm{n} 1)(\mathrm{n} 2) \\
(\mathrm{n} 3)(\mathrm{n} 4)(\mathrm{n} 5)\end{array}$ & $\begin{array}{l}\text { nya ya saat melihat anak-anak } \\
\text { dari teman yang seusia B sudah } \\
\text { sekolah ataupun hal-hal lain yang } \\
\text { B belum bisa lakukan, tapi ga } \\
\text { begitu terasa banget kalau } \\
\text { sekarang si mba (n3) }\end{array}$ \\
\hline
\end{tabular}

\section{SIMPULAN}

Berdasarkan hasil penelitian yang telah dilakukan, dapat disimpulkan bahwa orangtua yang memiliki anak dengan cerebral palsy dapat menerima keadaan anak tersebut setelah melalui pergulatan batin yang cukup hebat, hingga akhirnya dapat menerima kondisi anak mereka dengan lapang dada. Butuh waktu yang cukup lama bagi beberapa Orang tua untuk dapat menerima kondisi anak mereka. Cara yang dilakukan para orangtua untuk dapat menerima kondisi anak yaitu dengan cara bersyukur, berserah pada yang kuasa, bergaul dan berbagi informasi dengan sesama orangtua dari anak dengan cerebral palsy. Dukungan dari orang-orang terdekat juga menjadi salah satu faktor yang membuat proses penerimaan menjadi lebih mudah dijalani oleh orangtua. Penelitian ini hanya melibatkan 5 partisipan, sehingga kompleksitas penerimaan orang tua yang memiliki anak cerebral palsy akan lebih mendalam jika melibatkan partisipan yang lebih banyak dan dapat memberi gambaran yang lebih holistik.

\section{DAFTAR PUSTAKA}

Akbar, S., \& Woods, K. (2020). Understanding Pakistani parents' experience of having a child with special educational needs and disability (SEND) in England. European Journal of Special Needs Education, $\quad 0(0), \quad 1-16$. http://doi.org/10.1080/08856257.2020. 1748428

Amodei, M. L., Jalongo, M. R., Myers, J., Onchwari, J., \& Gargiulo, R. M. 
(2013). Survey of Publication Outlets in Early Childhood Education: Descriptive Data, Review Processes, and Advice to Authors. Early Childhood Education Journal, 41(2), 115-123.

http://doi.org/10.1007/s10643-0120555-4

Anindita, A. R., \& Apsari, N. C. (2020). Pelaksanaan Support Group Pada Orangtua Anak Dengan Cerebral Palsy. Focus: Jurnal Pekerjaan Sosial, 2(2), 208. http://doi.org/10.24198/focus.v2i2.262 48

Aran, Salev, B. \& G. (2007). Gaya Pengasuhan Berdampak pada Kualitas Hidup di Indonesia Anakanak dengan Cerebral palsy. Jurnal Pediatri, 151(1), 56-60.

Biswas, S., Moghaddam, N., \& Tickle, A. (2015). What are the factors that influence parental stress when caring for a child with an intellectual disability? A critical literature review. International Journal of Developmental Disabilities, $\quad 61(3), \quad$ 127-146. http://doi.org/10.1179/2047387714Y.00 00000043

Cohen, E. (2004). Parental Belief Systems and Difficulties in Parenting: Using the Parental Awareness Scheme As A Therapeutic Guide. Journal of Infant, Child, and Adolescent Psychotherapy, 3(2), 252-269. http://doi.org/10.1080/1528916030934 8464

Davies, D. (2011). Child development: A practitioner's Guide, third edition (Third Edit). New York: The Guilford Press.

Dwairy, M. (2009). Parental Acceptance
Rejection: A Fourth Cross-Cultural Research On Parenting And Psychological Adjustment Of Children. Journal of Child and Family Studies, 19(1), 30-35.

Eliyanto, H., \& Hendriani, W. (2013). Hubungan Kecerdasan Emosi dengan Penerimaan Ibu Terhadap Anak Kandung yang Mengalami Cerebral Palsy. Jurnal Psikologi Pendidikan Dan Perkembangan, 2(2), 124-130.

Fernández-García, C.-M., RodríguezMenéndez, C., \& Peña-Calvo, J.-V. (2017). Parental control in interpersonal acceptance-rejection theory: a study with a Spanish sample using Parents' Version of Parental AcceptationRejection/Control Questionnaire. Anales de Psicología, 33(3), 652. http://doi.org/10.6018/analesps.33.3.2 60591

Filus, A., \& Roszak, J. (2014). Relationships Between Parental Power, Prestige, and Acceptance, and the Psychological Adjustment of Young Adults in Poland. Cross-Cultural Research, 48(3), 286-294. http://doi.org/10.1177/1069397114528 458

Glavak-Tkalić, R., \& Kukolja-Cicmanović, R. (2014). Effects of Perceived Parental Acceptance-Rejection and Interpersonal Power-Prestige on the Psychological Adjustment of Croatian Adolescents. Cross-Cultural Research, 48(3), 231-239. http://doi.org/10.1177/1069397114528 298

Grace, R., Bowes, J., \& Elcombe, E. (2014). 
Child Participation and Family Engagement with Early Childhood Education and Care Services in Disadvantaged Australian Communities. International Journal of Early Childhood, 46(2), 271-298. http://doi.org/10.1007/s13158-0140112-y

Grisham-Brown, J., \& Mccormick, K. M. (2013). Lessons Learned from Work with International Partners to Inform Rural Practices for Early Childhood Intervention. Rural Special Education Quarterly, 32(32), 3-10. Retrieved from

http://journals.sagepub.com.ezproxy. library.wisc.edu/doi/pdf/10.1177/8756 87051303200102

Harjani, H. J. (2020). Interaksi Sosial Anak Nonreguler di SLB Zinnia Jakarta. JECE (Journal of Early Childhood Education), 2(1), 49-61.

Harris, T., \& Steyn, M. (2014). From your perspective: Black preservice early childhood education students share their stones. Australasian Journal of Early Childhood, 39(1), 4-11. Retrieved from

http://search.ebscohost.com/login.asp $\mathrm{x}$ ?direct=true $\& \mathrm{db}=\mathrm{aph} \& \mathrm{AN}=9552510$ $1 \&$ site $=$ ehost-live

Ikasari, A., \& Kristiana, I. F. (2017). Hubungan antara Regulasi Emosi dengan Stres Pengasuhan Ibu yang Memiliki Anak Cerebral Palsy. Jurnal Empati, 6(4), 323-328.

Jones, P. R. (1991). Stress Management for Parents of Children with Special Educational Needs. Educational Psychology in Practice, 6(4), 194-198. http://doi.org/10.1080/0266736910060
404

King, G., Baxter, D., Rosenbaum, P., Zwaigenbaum, L., \& Bates, A. (2009). Belief systems of families of children with autism spectrum disorders or Down syndrome. Focus on Autism and Other Developmental Disabilities, 24(1), 50-64.

http://doi.org/10.1177/1088357608329 173

Kusumah, M. Y. (2017). Pengalaman Ibu Dalam Merawat Anak Cerebal Palsy di Kabupaten Sumedang. Jurnal Sehat Masada, 10(2), 162-178.

Leitch, S., Sciberras, E., Post, B., Gerner, B., Rinehart, N., Nicholson, J. M., \& Evans, S. (2019). Experience of stress in parents of children with ADHD: A qualitative study. International Journal of Qualitative Studies on Health and Well-Being, 14(1). http://doi.org/10.1080/17482631.2019. 1690091

Lindsay, S., Proulx, M., Scott, H., \& Thomson, N. (2014). Exploring teachers' strategies for including children with autism spectrum disorder in mainstream classrooms. International Journal of Inclusive Education, 18(2), 101-122. http://doi.org/10.1080/13603116.2012. 758320

Machado, M., Machado, F., Neves, S., \& Fávero, M. (2014). How Do Parental Acceptance-Rejection, Power, and Prestige Affect Psychological Adjustment? A Quantitative Study With a Sample of Portuguese College Students. Cross-Cultural Research, 48(3), 295-304. http://doi.org/10.1177/1069397114528 
Bagaimana Menjadi Orang... -Yubaedi Siron, Veda Ria Perdana, Sri Rahayu Saputri, Dewi Nur Hanifah

459

Macintyre, C. (2007). Understanding Children's Development in the Early Years. Questions practioners frequently ask. http://doi.org/10.1037/032136

McFarland-Piazza, L., \& Saunders, R. (2012). Hands-on parent support in positive guidance: early childhood professionals as mentors. Australasian Journal of Early Childhood, 37(1), 65-73.

Meiza, A., Kardinah, N., Rahman, A. A., \& Puspasari, D. (2019). Quantitative Profile of Family Acceptance of Children Special Need's Moslem Parents (Case Study at Rumah Terapi Aura). American Journal of Family Therapy, 47(4), 232-243. http://doi.org/10.1080/01926187.2019. 1635540

Perez Algorta, G., MacPherson, H. A., Youngstrom, E. A., Belt, C. C., Arnold, L. E., Frazier, T. W., ... Fristad, M. A. (2018). Parenting Stress Among Caregivers of Children With Bipolar Spectrum Disorders. Journal of Clinical Child and Adolescent Psychology, 47(sup1), S306-S320. http://doi.org/10.1080/15374416.2017. 1280805

Plows, V., \& Whitburn, B. (2017). Inclusive Education Making Sense of Everyday Practice. Inclusive Education. Rotterdam: Sense Publishers. http://doi.org/10.1007/978-94-6300866-2_14

Pradipta, R. F., \& Andajani, S. J. (2017). Motion Development Program for Parents of Child with Cerebral Palsy. Jurnal Penelitian Dan Pengembangan Pendidikan Luar Biasa, 4(2), 160-164.
Prasastiwi, B. H., \& Hardjanta, G. (2017). Penerimaan Diri Orangtua yang mempunyai Anak Cerebral Palsy. Jurnal Pemikiran Dan Penelitian Psikologi, 12(2), 100-107.

Puspitarini, Z. (2017). Hubungan antara Pengalaman Orang Tua dalam Perawatan Kualitas Hidup Anak Cerebral Palsy di Yogyakarta Tahun 2016. Jurnal Keperawatan Respati Yogyakarta, 4(1), 112-117.

Putnick, D. L., Bornstein, M. H., Lansford, J. E., Chang, L., Deater-Deckard, K., Di Giunta, L., ... Bombi, A. S. (2012). Agreement in Mother and Father Acceptance-Rejection, Warmth, and Hostility/Rejection/ Neglect of Children Across Nine Countries. Cross-Cultural Research, 46(3), 191223.

http://doi.org/10.1177/1069397112440 931

Richard M. Gargiulo, J. L. K. (2005). Young Children with Special Needs (Second Edi). Mason USA: Delmar Cengage Learning.

http://doi.org/10.15713/ins.mmj.3

Rohner, R. P. (2014). Parental Power and Prestige Moderate the Relationship Between Perceived Parental Acceptance and Offspring's Psychological Adjustment: Introduction to the International Father Acceptance-Rejection Project. Cross-Cultural Research, 48(3), 197213.

http://doi.org/10.1177/1069397114528 295

Rosenbaum P, Paneth N, Leviton A, et al. (2007). A report: the definition and classification of cerebral palsy April 
2006. Dev Med Child Neurol Suppl, 49(6), 480.

Sakdiyah, H. (2012). Penerimaan Orang Tua yang Memiliki Anak Penyandang Cerebral Palsy (Sebuah Studi Kasus). IAIN Surabaya.

Samuel Kirk, James J Gallagher, Mary Ruth Coleman, N. A. (2009). Educating Exceptional Children Twelfth Edition (Twelfth Ed). USA: Cengage Learning.

Sarimski, K., Hintermair, M., \& Lang, M. (2013). Parent stress and satisfaction with early intervention services for children with disabilities - a longitudinal study from Germany. European Journal of Special Needs Education, 28(3), 362-373. http://doi.org/10.1080/08856257.2013. 797706

Siron, Y. (2019). Keterlibatan Orang Tua, Regulasi Diri, Agresivitas Mempengaruhi Perilaku Toleran Anak: Path Analysis. Awlady: Jurnal Pendidikan Anak, 5(1), 126-149. http://doi.org/10.24235/awlady.v5i1.3 698

Varan, A., Rohner, R. P., \& Eryuksel, G. (2008). Intimate partner acceptance, parental acceptance in childhood, and psychological adjustment among American adults in ongoing attachment relationships. CrossCultural Research, 42(1), 13-22. http://doi.org/10.1177/1069397107309 750

Wahyuni, P. D. (2017). Penerimaan Ibu terhadap Anak Cerebral Palsy. Universitas Mercubuana Yogyakarta.

Whittingham, K., Sanders, M., McKinlay, L., \& Boyd, R. N. (2013). Stepping Stones Triple $\mathrm{P}$ and Acceptance and Commitment Therapy for Parents of Children with Cerebral Palsy: Trial Protocol. Brain Impairment, 14(2), 270280.

http://doi.org/10.1017/BrImp.2013.19

Wulandari, R. S., \& Suryanto. (2020). Penerimaan orangtua pada anak cerebral palsy. Surabaya. 